\title{
Kebijaksanaan dan Pengaruhnya Terhadap Kinerja Perusahaan Industri Fotografi di Kota Bandar Lampung
}

${ }^{1}$ Muhiddin Sirat, Fakultas Ekonomi dan Bisnis (FEB) Universitas Lampung (Unila), Indonesia

${ }^{2}$ Imam Awaluddin, Fakultas Ekonomi dan Bisnis (FEB) Universitas Lampung (Unila), Indonesia

${ }^{3}$ Shandi Farizki, Fakultas Ekonomi dan Bisnis (FEB) Universitas Lampung (Unila), Indonesia

\section{Informasi Naskah}

Submitted: 10 Oktober 2019

Revision: 5 November 2019

Accepted: 10 November 2019

\section{Kata Kunci:}

Struktur Pasar, Kebijaksanaan, Kinerja Usaha

\begin{abstract}
This study aims to analyze the market structure and application of company policies in the photography industry in Bandar Lampung City and their effects on business performance. The first analytical tool used is the Herfindahl Index and Market Share to measure the market structure. Second, correlation analysis to measure the relationship between market structure and the achievement of targets for the implementation of company policy. Finally, multiple linear regression analysis to measure the effect of the target achievement of the implementation of company policy on business performance. The results showed that: (1). The structure of the photography industry market in Bandar Lampung City is a monopolistic competition market with a Herfindahl Index $=0.06103$ approaching 0; (2). The market structure has a low correlation with the achievement of the target of applying price policy Rxy $<0.5$ ), and (3). The achievement target of the implementation of company policy (price policy, product policy, marketing and promotion policy, service policy to consumers) has a significant positive effect on business performance.
\end{abstract}

\begin{abstract}
Abstrak
Penelitian ini bertujuan untuk menganalisis struktur pasar dan penerapan kebijaksanaan perusahaan pada industri fotografi di Kota Bandar Lampung serta pengaruhnya terhadap kinerja usaha. Alat analisis pertama yang digunakan yaitu Indeks Herfindahl dan Market Share untuk mengukur struktur pasar. kedua, analisis korelasi untuk mengukur hubungan antara struktur pasar dengan capaian target penerapan kebijaksanaan perusahaan. Terakhir, analisis regresi linier berganda untuk mengukur pengaruh capaian target penerapan kebijaksanaan perusahaan terhadap kinerja usaha. Hasil penelitian menunjukan bahwa: (1). Struktur pasar industri fotografi di Kota Bandar Lampung merupakan pasar persaingan monopolistik dengan besaran Indeks Herfindahl $=0,06103$ mendekati 0 ; (2). Struktur pasar berkorelasi rendah terhadap capaian target penerapan kebijaksanaan harga $R x y<0,5)$, dan (3). Capaian target penerapan kebijaksanaan perusahaan (kebijaksanaan harga, kebijaksanaan produk, kebijaksanaan pemasaran dan promosi, kebijaksanaan layanan kepada konsumen) berpengaruh positif signifikan terhadap kinerja usaha.
\end{abstract}

* Corresponding Author.

Muhiddin Sirat, e-mail: sahidin.1968@gmail.com
DOI: https://doi.org/10.23960/jep.v8i.61 


\section{PENDAHULUAN}

Pengertian industri menurut Lipezynski dalam Lincolin Arsyad (2014: 4) adalah sejumlah perusahaan yang memproduksi dan menjual sejumlah produk yang serupa, memanfaatkan teknologi yang serupa dan mungkin juga mengakses faktor produksi (input) dari pasar faktor produksi yang sama.Ditinjau dari segi banyaknya tenaga kerja, Industri di Indonesia dapat digolongkan kedalam beberapa empat golongan,yaitu: (1).Industri besar, memiliki jumlah tenaga kerja 100 orang atau lebih, (2).Industri sedang, memiliki jumlah tenaga kerja antara 20-99 orang, (3).Industri kecil, memiliki jumlah tenaga kerja antara 5-19 orang, dan (4). Industri rumah tangga, memiliki jumlah tenaga kerja antara 1-4 orang (Badan Pusat Statistik , 2017).

Sektor Industri kecil dan menengah saat ini memiliki peran untuk menciptakan peluang usaha bahkan telah menjadi tumpuan dan harapan sebagian masyarakat demi mengurangi pengangguran. Dilain pihak dalam mengembangkan industri kecil dan menengah di Indonesia, para pelaku usaha masih sering menghadapi kendala, antara lain berupa keterbatasan modal, tekhnologi produksi dan kapasitas produksi, kemampuan manajemen usaha, serta kendala dari segi penguasaan pengetahuaan dan informasi.

Sebagai bagian dari industri, perusahaan-perusahaan dalam industri kecil dan menengah beragam, ada yang berusaha dalam bidang produksi, usaha perda-gangan, dan usaha jasa. Industri jasa memiliki peran penting dalam mendukung pertumbuhan ekonomi yang berkelanjutan dan mening-katkan taraf hidup masyarakat melalui perluasan lapangan usaha dan memperluas kesempatan kerja, mendorong pembangunan daerah, meningkatkan pemerataan pen-dapatan masyarakat, serta mengentaskan masyarakat dari kemiskinan. Secara rata-rata besarnya kontribusi sektor jasa (industri jasa) terhadap PDRB Kota BandarLampung atas dasar harga berlaku tahun 2010-2014 adalah sebesar 0.34\% per tahun dengan tingkat pertumbuhan rata-rata sebesar 12.44\% pertahun (Badan Pusat Statistik Kota Bandar Lampung, 2017).

Dalam konteks ekonomi kreatif, sebagian dari industri jasa dapat di kelompokkan ke dalam industri kreatif, yaitu industri berbasis dari ekonomi kreatif. Industri kreatif adalah industri yang berasal dari pemanfaatan kreativitas, keteram-pilan serta bakat individu untuk menciptakan kesejahteraan serta lapangan pekerjaan melalui penciptaan dan pemanfaatan daya kreasi dan daya cipta individu tersebut. Industri kreatif dibagi menjadi 14 bidang, yaitu : arsitektur, desain, fashion, film, video dan fotografi, kerajinan, layanan computer dan piranti lunak, music, pasar dan barang seni, penerbit dan percetakan, periklanan, permainan inter aktif, riset dan pengembangan, pertunjukan, serta televisi dan radio (Kementrian Perdagangan RI, 2008).

Salah satu lapangan usaha industri kreatif tesebut adalah film, video dan fotografi. Seiring peralihan teknologi kearah digital, perlahan kegiatan fotografi mulai dilirik menjadi lahan bisnis yang digeluti saat ini. Hal tersebut tidak lepas dari kepraktisan dan kemudahan yang ditawarkan oleh teknologi digital saat ini.Kemajuan teknologi, khususnya dalam industri fotografi yang terus berkembang, menyebabkan banyak perusahaan penyedia jasa fotografi membuat pilihan konsumen menjadi semakin beragam.

Industri jasa fotografi di kota Bandar Lampung sendiri merupakan industri yang berpotensi untuk dikembangkan, mengingat Kota Bandar Lampung sendiri merupakan Ibukota Propinsi Lampung dan letaknya strategis sehingga banyak konsumen akan mencari jasa fotografi ini untuk mengabadikan momen mereka.

Terhitung tahun 2005 - 2018, terdapat 20 perusahaan pengelolaan jasa fotografi di Bandar Lampung tersebar di berbagai wilayah di kota Bandar Lampung (Badan Pusat Statistik Kota Bandar Lampung, 2018).

Industri jasa fotografi memiliki potensi untuk berkembang yang diindikasikan peningkatan jumlah permintaan/kebutuhan akanjasa fotografi itu sendiri, seperti pass foto, foto keluarga, foto wisuda, prewedding, wedding serta kebutuhan foto yang lainnya. Dilain pihak perusahaan dalam industri jasa fotografi ini masih memiliki kendala yang dihadapi, antara lain adalah selera konsumen yang beragam, membutuhkan modal yang cukup besar, dan tingkat persaingan usaha yang semakin ketat.

Struktur pasar (Market Structure) menunjukan atribut yang mempengaruhi sifat persaingan di pasar. Unsur-unsur struktur pasar dimaksud, terdiri dari : konsentrasi, diferensiasi produk, hambatan masuk ke pasar, struktur biaya, dan tingkat pengaturan pemerintah. Struktur 
pasar penting, karena struktur pasar menentukan prilaku perusahaan yang kemudian menentukan kinerja industri (Jaya Kirana, 2001).

Perilaku/kebijaksanaan (conduct) perusahaan dalam industri merupakan pola tanggap dan penyesuaian perusahaan dalam suatu industri/pasar untuk mencapai tujuannya. Bentuk struktur pasar dari suatu industri akan direspon oleh perusahaan-perusahaan dalam suatu industri tersebut melalui berbagai kebijaksanaan perusahaan (kebijaksanaan harga dan non harga) dalam upaya mencapai tujuan/kinerja perusahaan .Jika perilaku/kebijaksanaan perusahaan terlaksana dengan baik dan bersesuaian dengan struktur pasar yang dihadapinya, maka perusahaan dalam industi akan mencapai tujuannnya dengan baik pula. Oleh karena itu kinerja industri merupakan hasil pencapaian tujuan oleh semua perusahaan dalam suatu industri.Kirana Jaya(2001) menjelaskan bahwa kinerja dalam kaitan ekonomi memiliki banyak aspek namun para ekonom memusatkan pada tiga aspek pokok yaitu efisiensi, kemajuan teknologi dan keseimbangan dalam distribusi.

\section{Pengertian Industri}

Industri dalam arti sempit adalah kumpulan perusahaaan yang menghasilkan produk sejenis dimana terdapat kesamaan dalam bahan baku yang digunakan, proses, bentuk produk akhir, dan konsumen akhir. Menurut Hasibuan (1994) industri adalah kumpulan perusahaan perusahaan yang menghasilkan barang barang yang Homogen, atau barang barang yang mempunyai sifat saling menggantikan yang sangat erat. Dalam arti yang lebih luas, industri dapat didefinisikan sebagai kumpulan perusaahaan yang memproduksi barang dan jasa dengan elastisitas silang yang positif dan tinggi (Kuncoro, 2007).

\section{Pengertian dan Tujuan Perusahaan}

Dalam teori perusahaan, Nurimansyah Hasibuan (1994) menyatakan perusahaan tidak ditempatkan sebagai organisasi nyata, melainkan sebagai abstraksi dari bisnis yang ideal. Perusahaan dapat pula diartikan sebagai sebagai organisasi nyata, dimana secara legal terdapat pemilik dengan satu atau lebih karyawan, karyawan mendapat imbalan gaji dan pemilik sebagai entrepreneur menerima pendapatan yang tersisa atau keuntungan.

Dalam model maksimisasi keuntungan memandang makasi-misasi keuntungan seolaholah merupakan satu-satunya tujuan perusahaan. Dalam teori alternatif tentang tujuan perusahaan, keuntungan maksimum bukan satu-satunyatujuan perusahaanserta mengalami variasi dan berkembang luas. Muhammmad Teguh (2013 : 12), menjelaskan bahwa ada tujuan perusahaan dapat diringkas sebagai berikut :

1. memaksimumkan keuntungan, baik dalam jangka pendek maupun jangka panjang,

2. apresiasi modal atas investasi harta perusahaan,

3. memaksimum penjualan,

4. memaksimum pertumbuhan perusahaan,

5. Memaksimum andil perusahaan,

6. Stabilitas harga,

7. Stabilitas Output,

8. kepuasan, dan

9. tujuan etika (mencipta kan manfaat sebagai tanggungjawab sosial).

Dalam mempelajari perilaku perusahaan dalam suatu industri, sayogyanya berpijak pada perkembangan tujuan dan variasi tujuan perusahaan dalam bisnis. Hasil pencapaian tujuan perusahaan mencerminkan kinerja perusahaan dalam industri, dan kinerja industri merupakan hasil pencapaian tujuan oleh semua perusahaan dalam suatu industri.

\section{Kebijaksanaan/Perilaku(Conduct) perusahaan dalam industi}

Perilaku Perusahaan dalam suatu industri adalah pola tanggap dan penyesuaian perusahaan dalam suatu industri/pasar untuk mencapai tujuannya. Howe dalam Muhammad Teguh (2013: 24) mengelompokkan kebijaksanaan/perilaku (conduct) yang diterapkan perusahaan dalam industri kedalam : (1). kebijaksanaan harga (price policies), (2). Kebijak- 
sanaan produk (product policies), dan (3). kebijaksanaan penjualan (sales policies).

Bentuk/Struktur pasar akan menimbulkan kebijakan perusahaan (Kebijakan harga dan non harga) yang berbeda pada masing-masing bentuk pasar yang dihadapinya. Jika perilaku/kebijaksanaan perusahaan dalam industri bersesuaian dengan struktur pasar yang dihadapinya, maka perusahaandalam industi akan mencapai tujuannnya.

\section{Struktur Pasar}

Joe S Bain dalam Nurimasjah Hasibuan (1994) mendefinisikan struktur pasar sebagai karakteristik organisasi pasar yang mempengaruhi sifat kompentisi atau persaingan dan harga didalam pasar.

\section{Hubungan Struktur Prilaku dan Kinerja}

Studi ilmu ekonomi industri memperlihatkan antara struktur pasar (market structure), perilaku pasar (market conduct), dan kinerja pasar (market performance) memiliki hubungan keterkaitan yang sangat erat. Struktur pasar menentukan perilaku perusahaan industri, dan perilaku perusahaan industri menentukan keadaan kinerja perusahaan dalam industri.Begitu pula sebaliknya kinerja perusahaan dalam industri menentukan struktur pasar, dan struktur pasar menentukan perilaku perusahaan dalam industri/pasar (Muhammad Teguh, $2013: 22$ ).

\section{Tabel 1.}

\section{Struktur Pasar dan Kondisi Pasar}

\begin{tabular}{ll}
\hline \multicolumn{1}{c}{ Jenis Pasar } & \multicolumn{1}{c}{ Kondisi Pasar } \\
\hline Monopoli murni & $\begin{array}{l}\text { Suatu perusahaan yang memiliki Suatu perusahaan } \\
\text { yang memiliki }\end{array}$ \\
$\begin{array}{l}\text { Perusahaan yang dominan } \\
\text { ( Persaingan murni) }\end{array}$ & $\begin{array}{l}50-100 \text { persen dari pangsa pasar dan tanpa pesaing } \\
\text { yang kuat. }\end{array}$ \\
Oligopoli ketat & $\begin{array}{l}\text { Penggabungan empat perusahaan terkemuka yang } \\
\text { memiliki pangsa pasar 60-100 persen, kesepakatan } \\
\text { diantara mereka untuk menetapkan harga relatif }\end{array}$ \\
& mudah. \\
Oligopoli longgar & mengabungan empat perusahaan terkemuka yang \\
& kesepakatan mereka untuk mendapatkan harga \\
& sebenarnya tidak mungkin. \\
& Banyak pesaing yang efektif, tidak satu pun yang \\
Persaingan monopolistik & memiliki lebih dari10 persen pangsa pasar. \\
& Lebih dari 50 pesaing yang mana tidak satu pun yang \\
Persaingan murni & memiliki pangsa pasar.
\end{tabular}

Sumber : Kirana Jaya, 2001.

Struktur biasanya diukur dengan rasio konsentrasi. Untuk mendapatkan hipotesis terkait hubungan antara struktur pasar, prilaku dan kinerja pasar, menggunakan asumsi dalam SCP yaitu : Adanya hubungan yang stabil dan adanya arah kausalitas dari struktur-prilaku-kinerja, dan pendekatan SCP berawal dari premis bahwa pengukuran kekuatan pasar dapat dihitung dari data yang tersedia.

\section{Pengertian Fotografi}

Fotografi adalah proses melukis/menulis dengan menggunakan media cahaya. Sebagai istilah umum, fotografi berarti proses atau metode untuk menghasil kan gambar atau foto dari suatu objek dengan merekam pantulan cahaya yang mengenai objek tersebut pada media yang peka cahaya. Alat paling populer untuk menangkap cahaya ini adalah kamera, tanpa cahaya, tidak ada foto yang bisa dibuat (Darwis Triadi, 2008).

Prinsip fotografi adalah memfokuskan cahaya dengan bantuan pembiasan sehingga mampu membakar medium penangkap cahaya. Medium yang telah dibakar dengan ukuran luminitas cahaya yang tepat akan menghasil kan bayangan identik dengan cahaya yang 
memasuki medium pembiasan (selanjut nya disebut lensa).

Intensitas cahaya yang tepat untuk menghasilkan gambar, digunakan bantuan alat ukur berupa lightmeter. Setelah mendapat ukuran pencahayaan yang tepat, seorang fotografer bisa mengatur intensitas cahaya tersebut dengan mengubah kombinasi ISO/ASA (ISO Speed), diafragma (Aperture), dan kecepatan rana (speed). Kombinasi antara ISO, Diafragma \& Speed disebut sebagai pajanan (Darwis Triadi, 2008). Fotografi saat ini telah berkembang menjadi sebuah gaya hidup, hal ini dimulai semenjak munculnya era digital dan berkembangnya sosial media.

\section{Kerangka Pemikiran}

Langkah awal yang dilakukan dalam penelitian ini adalah melihat struktur pasar industri jasa fotografi di kota Bandar Lampung dengan menggunakan indeks indeks herfindal dan market share. Dari hasil pengukuran ini maka akan diperoleh posisi struktur pasar industri fotografi. Apakah industri fotografi berada pada pasar monopoli, oligopoli longgar, oligopoli ketat, persaingan monopolistik, atau persaingan murni.

Kualitas penerapan kebijak-sanaan / perilaku perusahaan dalam industri dapat diukur dengan cara mengukur capaian taget penerapan kebijaksanaan produk, kebijak-sanaan harga, kebijaksanaan pemasaran dan promosi, serta penerapan kebijaksanaan layanan kepada konsumen. Perilaku perusahaan dalam suatu industri akan berpengaruh terhadap kinerja usaha perusahaan yana berada dalam industri tersebut.

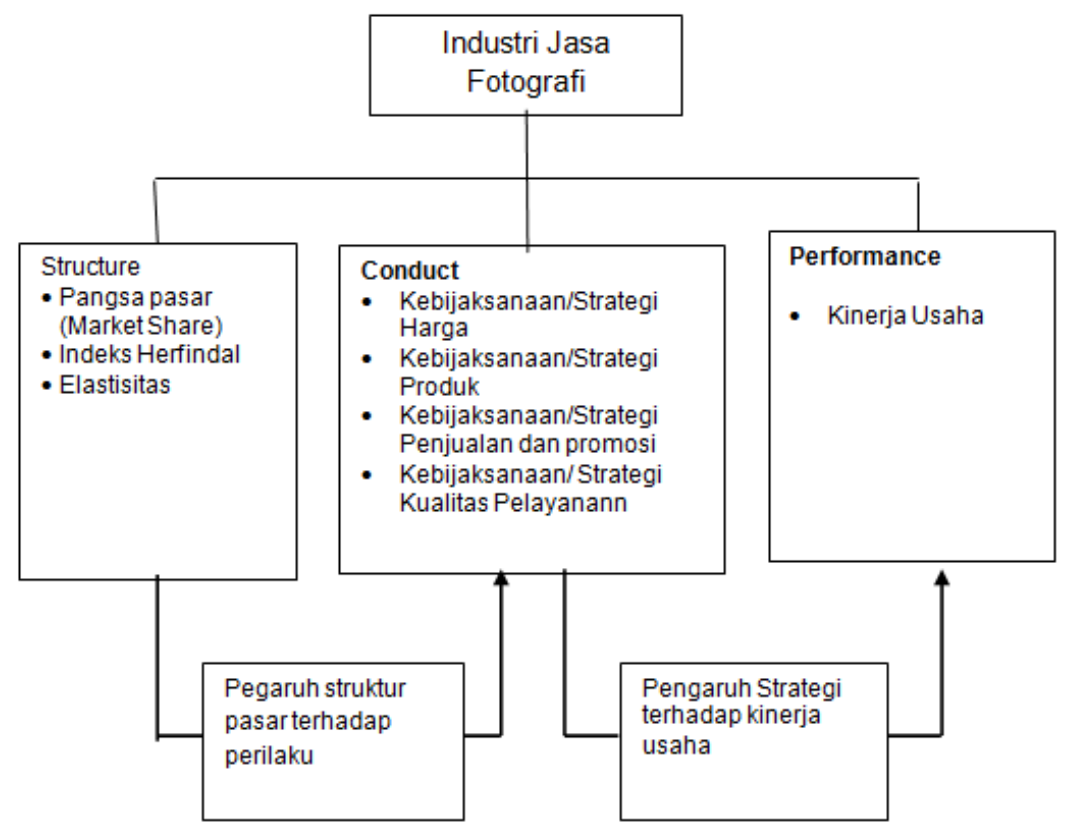

\section{Gambar 1. Skema Kerangka Pemikiran}

\section{METODOLOGI PENELITIAN}

\section{Jenis dan Sumber Data}

Ditinjau dari segi eksplanasi variabel, penelitian ini dapat dinyatakan sebagai penelitian deskriptif kuantitatif dan asosiatif, dalam arti : (1).penelitian ini memiliki tujuan untuk mendeskripsikan setiap variabel yang termasuk dalam variabel kualitas implementasi kebijaksanaan/strategi perusahaan secara parsial tanpa membandingkannya dan bukan pula untuk menghubungkannya dengan variabel lainnya, dan (2).bersifat asosiatif dalam arti ingin mengukur pengaruh masing-masing variabel yang termasuk dalam variabel kualitas implementasi kebijak-sanaan/strategi usaha terhadap kinerja usaha perusahaan dalam industri jasa fotografi. 
Jenis data yang dibutuhkanuntuk mendukung penelitian ini adalah data kuantitatif dan data kualitatif. Data Kuantitatif adalah data data yang berbentuk angka dengan menggunakan skala rasio, skala interval, skala ordinal, dan skala nominal. Data kualitatif yaitu data yang dinyatakan dalam bentuk kata, kalimat, dan atau gambar.

Selanjutnya dari segi sumber data, data dalam penelitian ini dikelompokkan dalam : (1).Data primer, yaitu data yang langsung diperoleh dari responden pengusaha sampel dalam industri jasa fotografi dengan menggunakan metode survei, dan (2). data sekunder, yaitu data yang diperoleh secara tidak langsung dari objek yang diteliti, melainkan diperoleh dari buku-buku laporan penelitian, laporan dinas instansi yang terkait, dan sumber lain yang telah terpublikasi melalui studi pustaka.

\section{Uji Validitas dan Reliabilitas Instrumen Penelitian}

Uji validitas adalah suatu langkah pengujian yang dilakukan terhadap isi (content) dari suatu instrumen, dengan tujuan untuk mengukur ketepatan instrumen yang digunakan dalam suatu penelitian (sugiyono, 2006). Untuk menguji validitas konstruk dilakukan dengan cara mengkorelasikan antara skor butir pertanyaan dengan skor totalnya.

Uji Reliabilitas berkenaan dengan tingkat ketetapan hasil pengukuran (Nana Syaodih Sukmadinata, 2009). Kuesioner dikatakan reliabel jika dapat memberikan hasil relatif sama pada saat dilakukan pengukuran kembali pada obyek yang berlainan pada waktu yang berbeda atau memberikan hasil yang tetap.Uji reliabilitas dilakukan dengan rumus cronbachalpha sebagai berikut:

$$
\mathrm{R}_{11}=\left[\frac{k}{(k-1)}\right]\left[1-\frac{\sum \sigma_{b}^{2}}{\sigma_{t}^{2}}\right]
$$

Apabila koefisien Cronbach Alpha $\left(r_{11}\right) \geq 0,7$ maka dapatdikatakan instrumen tersebut reliabel (Johnson \& Christensen, 2012).

Tabel 2.

Operasionalisasi Variabel Penelitian

\begin{tabular}{|c|c|c|c|c|}
\hline No. & Variabel & Sub Variabel & Indikator & $\overline{\text { Skala }}$ \\
\hline 1 & $\begin{array}{l}\text { Kebijaksanaan/ } \\
\text { Strategi } \\
\text { (Conduct) }\end{array}$ & 1.1 Strategi Produk & $\begin{array}{l}\text { a. Jumlah jenis paket fotografi } \\
\text { yang terjual } \\
\text { b. Keragaman jenis paket (jasa } \\
\text { fotografi) yang diminati } \\
\text { konsumen } \\
\text { c. Kualitas produk danbahan } \\
\text { baku } \\
\text { d. Penetapan konsep studio } \\
\text { e. Pengemasan hasil (produk) }\end{array}$ & $\begin{array}{l}\text { Ordinal } \\
\text { Ordinal } \\
\text { Ordinal } \\
\text { Ordinal } \\
\text { Ordinal }\end{array}$ \\
\hline & & 1.2 Strategi Harga & $\begin{array}{l}\text { a. Kesesuaian perubahan harga } \\
\text { dengan struktur pasar } \\
\text { b. Efektivitas penerapan } \\
\text { potongan } \\
\quad \text { harga } \\
\text { c. Perhatian terhadap harga } \\
\text { pesaing dalam penetapan harga } \\
\text { d. Perhatian terhadap biaya } \\
\text { perunit dalam penetapan harga }\end{array}$ & $\begin{array}{l}\text { Ordinal } \\
\text { Ordinal } \\
\text { Ordinal } \\
\text { Ordinal }\end{array}$ \\
\hline & & 1.3 Strategi Promosi & $\begin{array}{l}\text { Intensitas/keaktifanpelaksanaan: } \\
\text { a. Promosi Langsung } \\
\text { b. Penyebaran pamflet } \\
\text { c. Pemanfaatan Media } \\
\text { sosial }\end{array}$ & $\begin{array}{l}\text { Ordinal } \\
\text { Ordinal } \\
\text { Ordinal }\end{array}$ \\
\hline
\end{tabular}

1.4 Strategi kualitas

a. Ketersediaan Fasilitas

Ordinal

Pelayanan 


\begin{tabular}{|c|c|c|c|c|}
\hline \multirow{5}{*}{2} & & & $\begin{array}{l}\text { b. Perhatian terhadap keluhan } \\
\text { c. Intensitas penanganan } \\
\text { keluhan }\end{array}$ & $\begin{array}{l}\text { Ordinal } \\
\text { Ordinal }\end{array}$ \\
\hline & $\begin{array}{l}\text { Kinerja Usaha } \\
\text { (Performance) }\end{array}$ & 2.1 Jumlah paket & a. Jumlah paket yang diperoleh & Rasio \\
\hline & & 2.2 Nilai Penjualan & b. Omset / nilai penjualan & Rasio \\
\hline & & $\begin{array}{l}\text { 2.3 Persentase nilai } \\
\text { penjualan }\end{array}$ & $\begin{array}{l}\text { c. Persentase pertumbuhan nilai } \\
\text { penjualan }\end{array}$ & Rasio \\
\hline & & $\begin{array}{l}\text { 2.4 PencapaianTarget } \\
\text { Penjualan }\end{array}$ & $\begin{array}{l}\text { a. Pencapaian Target } \\
\text { Penjualan }\end{array}$ & Rasio \\
\hline
\end{tabular}

\section{Alat Analisis}

Analisis Deskriptif Kuantitatif

Indeks Herfindahl adalah ukuran konsentrasi dalam industri yang dihitung sebagai jumlah kuadrat dari pangsa pasar masing-masing perusahaan. Perumusan Indeks Herfindhal menurut Orris C.Herfindhal sebagai berikut :

$$
I H=\sum_{1=1}^{n-k}\left(\frac{x}{T}\right)^{2}
$$

Keterangan:

$\mathrm{n} \quad=$ jumlah perusahaan dalam suatu industri

$\mathrm{x} \quad=$ nilai penjualan perusahaan

$\mathrm{T} \quad=$ total nilai penjualan industri

$\mathrm{IH} \quad=$ Indeks Herfindahl

Indeks ini besarannya 0 s.d. 1, semakin kecil mendekati nol struktur pasar mengarah ke pasar persaingan murni dan sebaliknya semakin mendekati satu struktur pasar mengarah ke struktur pasar monopoli (Hasibuan, 1994).

\section{Analisisis Asosiatif}

Dalam menganalisis besarnya pengaruh varibel bebas terhadap variabel terikat, menggunakan model persamaan regresi linier berganda (Multiple Regression) dengan spesifikasi model linier sebagai berikut:

$$
Y=\beta_{0}+\beta_{1} X_{1}+\beta_{2} X_{2}+\beta_{3} X_{3}+\beta_{4} X_{4}+E t
$$

\begin{tabular}{|c|c|}
\hline Y & $=$ Kinerja Usaha \\
\hline $\mathrm{X}_{1}$ & $=$ Kualitas Implementasi Strategi Produk \\
\hline$X_{2}$ & $=$ Kualitas Implementasi Strategi Harga \\
\hline$X_{3}$ & = Kualitas Implementasi Strategi Promosi \\
\hline $\mathrm{X}_{4}$ & $=$ Kualitas Implementasi Strategi Layanan \\
\hline$\beta_{1}, \beta_{2}, \beta_{3}, \beta$ & $=$ Koefisien regresi \\
\hline$\alpha$ & $=$ Konstanta \\
\hline Et & $=$ Kesalahan (Error term) \\
\hline
\end{tabular}

\section{Keterangan :}

\section{Pengujian Asumsi Klasik}

Dalam pengujian asumsi klasik menggunakan Uji Normalitas, Uji Uji Heteroskedastisitas, Uji Auto-korelasi, dan Uji Multikolinieritas

\section{Pengujian Hipotesis Statistik :}




\section{Uji t}

Uji ini digunakan untuk mengetahui apakah dalam model regresi variabel independen $\left(\mathrm{X}_{1}\right.$,

$\mathrm{X}_{2}, \ldots, \mathrm{X}_{\mathrm{n}}$ ) secara parsial berpengaruh signifikan terhadap variabel dependen (Y). Uji t dilakukan untuk melihat hubungan atau pengaruh antara variabel bebas secara individual terhadap variabel terikat (Widarjono, 2016: 47).

Hipotesis:

Ho : $\beta \mathrm{i}=0$; Variabel bebas tidak berpengaruh terhadap variabel terikat

$\mathrm{Ha}: \beta \mathrm{i}>0$; Variabel bebas berpengaruh terhadap variabel terikat

\section{Uji F}

Uji ini digunakan untuk mengetahui apakah variabel independen $\left(X_{1}, X_{2}, \ldots, X_{n}\right)$ bersamasama berpengaruh secara signifikan terhadap variabel dependen $(\mathrm{Y})$

Hipotesis :

$\mathrm{Ho}: \beta \mathrm{i}=0$; tidak berpengaruh signifikan antara seluruh variabel bebas dengan variabel terikat

$\mathrm{Ha}: \beta \mathrm{i}>0$; ada pengaruh signifikan antara seluruh variabel bebas dengan variabel terikat.

Apabila: $\mathrm{F}_{\text {hitung }}>\mathrm{F}_{\text {Tabel }}$ : maka Ho ditolak dan Ha diterima, maka seluruh variabel bersamasama memiliki pengaruh signifikan terhadap variabel terikat. $\mathrm{F}_{\text {hitung }}<\mathrm{F}_{\text {Tabel }}$ : maka Ho diterima dan Ha ditolak, maka seluruh variabel bersama-sama tidak memiliki pengaruh signifikan terhadap variabel terikat. (Widarjono, 2016: 67)

\section{HASIL DAN PEMBAHASAN}

\section{Struktur Pasar}

Pangsa pasar (market share) adalah persentase dari total penjualan pada suatu target pasar yang diperoleh dari suatu perusahaan (potensi pasar dibagi dengan jumlah penjualan). Pangsa pasar merupakan bagian dari pasar yang dikuasai oleh suatu perusahaan dan seluruh potensi jual, umumnya dinyatakan dalam persentase. Persentase market share terendah 2,02 $\%$, tertinggi $9,09 \%$, dengan market share rata-rata 5,00 \% .

Hasil perhitungan market share tidak satupun perusahaan yang memiliki pangsa pasar yang berarti, tidak adanya perusahaan yang mendominasi pangsa pasar. Berdasarkan hasil pengujian kriteria pangsa pasar maka bentuk pasar mengarah pada pasar persaingan monopolistik.

Indeks Herfindal digunakan sebagai alat ukur distribusi penguasaan pasar atau konsentrasi pasar di dalam industriyang dihitung dengan cara menjumlah kuadrat dari pangsa pasar masing-masing perusahaan dalam suatu industri. Jika indeks herfindal menunjukan nilai 1 maka struktur pasar merupakan pasar monopoli, dan sebaliknya jika Indeks Herfindalmendekati nilai 0 berarti bahwa pangsa perusahaan dalam industri merata (tidak terkonsentrasi) dan mengarah kepada struktur pasar persaingan murni.

Hasil perhitungan Indeks Herfindahl pada industri fotografi di Bandar Lampung adalah sebesar 0,06103 mendekati nilai 0, yang berarti bahwa pangsa pasar perusahaan-perusahaan dalam industri ini relatif merata dan dapat dinyatakan bahwa struktur pasar industri foto grafi adalah pasar persaingan monopolistik .

Dalam pasar persaingan monopolistik, elastisitas harga dari permintaan bersifat elastis. Penerapan kebijaksanaan harga dalam arti menaikkan harga akan merugikan perusahaan karena akan menurunkan penerimaan total perusahaan. Capaian kondisi ideal atas penerapan kebijaksanaan harga baru mencapai $67 \%$ atau belum berada pada posisi yang sangat efektif, kondisi ini menyebabkan penerapan kebijakan harga berkorelasi rendah (yaitu sebesar 0,094280) dan tidak signifikan terhadap market share .

\section{Capaian Kondisi Ideal atas Penerapan Kebijaksanaan /Strategi Usaha}

Tingkat pencapaian target atas penerapan kebijaksanaan perusahaan dalam industri 
foto grafi di Kota Bandar Lampung disajikan pada table berikut ini.

\section{Implementasi Kebijaksanaan/strategi Produk}

Pencapaian kondisi ideal atas penerapan kebijaksanaan produk diukur dengan menggunakan lima aspek penilaian, yaitu : (1). jumlah pesanan dari setiap jenis paket fotografi yang di tawarkan, (2). keragaman jenis paket fotografi yang diminati konsumen, (3). mutu produk dan kualitas bahan baku, (4). penetapan konsep studio, dan (5) pengemasan hasil/produk.

Pencapaian kondisi ideal dari setiap aspek atas penerapan kebijaksanaan / strategi pengem-bangan produk pada industri fotografi adalah sebagai berikut : (1).pencapaian kondisi ideal aspek jumlah jenis paket fotografi yang di tawarkan sebesar 77 persen, (2).pencapaian kondisi ideal aspek keberagaman jenis paket fotografi yang ditawarkan kepada konsumensebesar 69 persen, (3).pencapaian kondisi ideal aspek mutu produk dan kualitas bahan baku sebesar 66 persen, (4). pencapaian kondisi ideal aspek ketepatan konsep studiosebesar 62 persen, dan (5) pencapaian kondisi ideal aspek kualitas dan tampilan kemasan produk mencapai 64 persen.

Tabel 2.

Tingkat Pencapaian Target atas Penerapan Kebijaksanaan Perusahaan Sampel dalam Industri Fotografi di Kota Bandar Lampung.

\begin{tabular}{llccc}
\hline No & Variabel & $\begin{array}{c}\text { Total } \\
\text { Skor Rill }\end{array}$ & $\begin{array}{c}\text { Total Skor } \\
\text { Harapan }\end{array}$ & $\begin{array}{c}\text { Pencapaian Kondisi } \\
\text { Ideal (\%) }\end{array}$ \\
\hline a. & $\begin{array}{l}\text { Kebijaksanaan/Strategi } \\
\text { Produk }\end{array}$ & 338 & 500 & 67,6 \\
b. & $\begin{array}{l}\text { Kebijaksanaan/Strategi } \\
\text { Harga }\end{array}$ & 264 & 400 & 66,0 \\
c. & $\begin{array}{l}\text { Kebijaksanaan/Strategi } \\
\text { Promosi }\end{array}$ & 294 & 400 & 73,5 \\
d. & $\begin{array}{l}\text { Kebijaksanaan/Strategi } \\
\text { Kualitas Layanan }\end{array}$ & 258 & 400 & 64,5 \\
\cline { 2 - 4 } & Jumlah & 1154 & 1700 & 271,6 \\
\cline { 2 - 4 } & Rata-Rata & 288,5 & 425 & 67,9 \\
\hline
\end{tabular}

Sumber: Rekapitulasi Data Primer Hasil Penelitian Survei 2019.

Berdasarkan tabel dan pembahasan di atas dapat disimpulkan bahwa kondisi pencapaian kondisi ideal atas penerapan kebijaksanaan produk cukup tercapai dan telah berjalan cukup efektif dengan rata-rata nilai pencapaian sebesar 67,6 persen. Persentase tertinggi pencapaian kondisi ideal strategi produk yaitu pada aspek jumlah jenis paket fotografi yang di tawarkan, hal ini berarti bahwa dalam strategi produk perusahaan jasa fotografi di Kota Bandar Lampung menekankan pada keberagaman paket yang dapat disesuaikan dengan kebutuhan dan minat konsumen.

\section{Implementasi Kebijaksanaan/Strategi Harga}

Pencapaian kondisi ideal atas penerapan kebijaksanaan harga yang di ukur dengan menggunakan empat aspek penilaian, yaitu : (1). kesesuaian antara besaran persentase perubahan harga dengan struktur pasar yang dihadapi, (2). tingkat efektivitas pemberlakuan potongan harga, (3). tingkat perhatian terhadap harga pesaing dalam penetapan harga, (4).tingkat perhatian terhadap biaya perunit dalam penetapan harga.

Pada aspek pencapaian kondisi ideal atas penerapan kebijaksanaan harga, pencapaian kondisi idealnya sebesar 66 persen yang berarti kondisi ideal yang diharapkan cukup tercapai. Industri jasa fotografi di Kota Bandar Lampung menerapkan diskriminasi harga dengan memberikan harga yang lebih murah bagi para perusahaan lain yang bekerja sama dengan industri fotografi terkait seperti wedding organizer. Dalam menetapkan harga industri fotografi di Kota Bandar Lampung memperhatikan harga pesaing. Metode yang diterapkan produsen dalam menentukan harga umumnya hampir sama yaitu berdasarkan ongkos dan harga pesaing.

Berdasarkan tabel diatas dapat disimpulkan bahwa rata rata pencapaian kondisi ideal atas penerapan kebijaksanaan/strategi harga cukup tercapai, dengan persentase capaian secara rata- 
rata sebesar 66 persen.

\section{Implementasi Kebijaksanaan/Strategi Promosi}

Pengukuran kualitas penerapan kebijaksanaan/strategi promosi pada industri jasa fotografi di Kota Bandar Lampung dilakukan dengan cara mengukur intensitas pelaksanaan promosi secara : (1).promosi langsung/lisan, (2).penyebaran pamflet, dan juga (3).memanfaatkan media sosial dalam kegitan promosi yaitu dengan membuat akun resmi industri fotografi pada aplikasi facebook, dan instagram.

Berdasarkan tabel diatas dapat disimpulkan bahwa rata rata pencapaian kondisi ideal atas penerapan kebijaksanaan/strategi promosi cukup tercapai, dengan persentase capaian secara rata-rata sebesar 73,5 persen.

\section{Implementasi Kebijaksanaan/Strategi Peningkatan Kuliatas Layanan}

Pada tabel di atas menyajikan persentase pencapaian kondisi ideal atas penerapan kebijaksanaan/ strategi peningkatan kualitas pelayanan yang diukur dengan empat aspek penilaian, yaitu : (1).aspek ketersediaan fasilitas yang diberikan kepada konsumen, (2).perhatian terhadap keluhan konsumen dan intensitas penaganan keluhan konsumen.

Sebagian besar industri fotografi di Kota Bandar Lampung memberikan fasilitas yang baik kepada seluruh konsumennya, seperti tempat yang nyaman, dekorasi ruang tunggu yang tidak membosankan, penyejuk ruangan, wifi dan ketersediaan air mineral di setiap ruang tunggu.

Industri fotografi di Kota Bandar Lampung cukup memperhatikan keluhan setiap konsumen. Keluhan yang sering di sampaikan konsumen yaitu keluahan yang terkait dengan ketidak sesuaian hasil foto dengan selera/keinginan konsumen.

Pencapaian kondisi ideal atas penerapan kebijaksanaan/strategi peningkatan kualitan pelayanan telah efektif dengan nilai rata-rata capaian sebesar 64 persen. Persentase tertinggi atas pencapaian kondisi ideal penerapan kebijaksanaan/strategi peningkatan kualitas pelayanan terletak pada intensitas penaganan keluhan konsumen yaitu sebesar 77 persen. Hal ini berarti bahwa dalam penerapan strategi peningkatan kualitas pelayanan industri fotografi menekankan untuk meminimalisir keluhan konsumen dengan melakukan pelayanan terbaik.

Pada tabel di atas menyajikan pencapaian kondisi ideal kinerja usaha. Persentase pencapaian kondisi ideal kinerja usaha dari aspek : (1).capaian target jumlah penjualan paket fotografi sebesar 75 persen. (2).kondisi nilai penjualan mencapai 65 persen, (3).capaian target pertumbuhan nilai penjualan sebesar 52 persen, dan (4).capaian target nilai penjualan berada pada pencapaian tertinggi yaitu sebesar 77 persen.

Berdasarkan tabel diatas dapat disimpulkan bahwa rata-rata pencapaian kondisi ideal kinerja usaha yang dilakukan cukup baik dengan rata-rata persentase pencapaian sebesar 67,25 persen.

\section{Pencapaian Kondisi Ideal Aspek Kinerja Usaha}

Tabel 3.

Capaian Kinerja Usaha Perusahaan-perusahaan pada Industri Jasa Fotografi di Kota Bandar Lampung.

\begin{tabular}{clccc}
\hline No & $\begin{array}{c}\text { Aspek Penilaian Tingkat } \\
\text { Efektivitas }\end{array}$ & $\begin{array}{c}\text { Total } \\
\text { skor riil }\end{array}$ & $\begin{array}{c}\text { Total Skor } \\
\text { Harapan }\end{array}$ & $\begin{array}{c}\text { Pencapaian Kondisi } \\
\text { Ideal (\%) }\end{array}$ \\
\hline 1. & Jumlah paket yang terjual & 75 & 100 & 75 \\
2. & Omset/Nilai penjualan & 65 & 100 & 65 \\
3. & $\begin{array}{l}\text { Persentase pertumbuhan } \\
\text { nilai penjualan }\end{array}$ & 52 & 100 & 52 \\
4. & $\begin{array}{l}\text { Pencapaian target Nilai } \\
\text { Penjualan }\end{array}$ & 77 & 100 & 77 \\
\hline & Jumlah & 269 & 400 & 269 \\
\hline & Rata-rata & 67,25 & 100 & 67,25 \\
\hline
\end{tabular}

Sumber: Rekapitulasi Data Primer Hasil Penelitian Survei 2019. 


\section{Pengaruh Implementasi Kebijaksanaan Perusahaan Terhadap Kinerja Usaha}

Tabel 4.

Hasil Estimasi Kinerja Usaha Industri Fotografi di Bandar Lampung

\begin{tabular}{lrlll}
\hline \hline \multicolumn{1}{c}{ Variable } & Coefficient & Std. Error & t-Statistic & Prob. \\
\hline \hline C & 5.309809 & 2.349615 & 2.259864 & 0.0391 \\
S_PRODUK & 0.180198 & 0.093231 & 1.932811 & 0.0724 \\
S_HARGA & 0.352440 & 0.180632 & 1.951153 & 0.0700 \\
S_PROMOSI & -0.322344 & 0.122593 & -2.629373 & 0.0190 \\
S_LAYANAN & 0.399136 & 0.150049 & 2.660038 & 0.0178 \\
\hline \hline R-squared & 0.767970 & Mean dependent var & 13.45000 \\
Adjusted R-squared & 0.706096 & S.D. dependent var & 2.114486 \\
S.E. of regression & 1.146325 & Akaike info criterion & 3.323318 \\
Sum squared resid & 19.71093 & Schwarz criterion & 3.572251 \\
Log likelihood & -28.23318 & Hannan-Quinn criter. & 3.371912 \\
F-statistic & 12.41172 & Durbin-Watson stat & 2.254471 \\
Prob(F-statistic) & 0.000118 & & & \\
\hline \hline
\end{tabular}

\section{Kebijaksanaan/Strategi Produk}

Hasil penelitian ditemukan bahwa banyak jenis paket fotografi yang ditawarkan setiap perusahaan dalam industri fotografi, namun secara menyeluruh jenis paket yang ditawarkan setiap perusahaan relatif homogensesuai dengan karakteristik pasar monopolistik yaitu jenis produk homogeny.

Aspek kualitas/mutu bahan baku akan mempengaruhi harga jual paket, proses untuk mendapatkan kualitas yang baik terletak pada bagaimana proses produksi dilakukan. Menurut para responden perusahaan, semakin beragamnya jenis paket yang disediakan perusahaan, semakin baik bagi konsumen untuk memilih jenis paket yang sesuai dengan keinginan dan kebutuhannya. Kemudian, aspek penentuan konsep studio ditentukan oleh perusahaan, karena setiap perusahaan memiliki konsep studio masing-masing. Pada aspek kemasan produk sebagian besar kemasan produk memiliki jenis yang sama dan yang membedakan hanya dalam ukuran kemasan, dengan kondisi tersebut diharapkan perusahaan diharapkan akan menciptakan kemasan yang lebih menarik guna meningkatkan kepercayaan konsumen.

Kualitas implementasi kebijaksanaan produk yang diindikasikan : (1).jumlah pesanan dari setiap jenis paket jasa fotografi yang di tawarkan, (2). Keragaman jenis paket fotografi yang diminati konsumen, (3).mutu produk dan kualitas bahan baku, (4).penetapan konsep studio, dan (5) pengemasan hasil (output) produk, berpengaruh positif signifikan terhadap kinerja usaha sebesar $\beta_{4}=0,180198$ dan $t_{\text {-statistic }}=1.932811>t_{\alpha, n-k-1}\left(t_{\text {-tabel }}=1,753\right)$.

\section{Kebijaksanaan/Strategi Harga}

Kualitas implementasi kebijaksanaan harga yang diindikasikan : (1). kesesuaian antara frekuensi dan besaran perubahan relative dari harga dengan struktur pasar yang dihadapi, (2). tingkat efektivitas pemberlakuan potongan harga, (3). tingkat perhatian terhadap harga pesaing dalam penetapan harga, dan (4). tingkat perhatian terhadap biaya produksi perunit (harga pokok produksi) dalam penetapan harga.

Berdasarkan hasil analisis deskriptif, skor total ideal atas penerapan strategi harga pada industri fotografi adalah sebesar 400 dengan skor total riil sebesar 264, yang berarti capaian kondisi ideal atas penerapan strategi harga sudah mendekati kondisi yang diharapkan, yaitu sebesar 66,0 persen. Selanjutnya hasil analisis asosiatif menunjukkan bahwa kualitas implementasi kebijaksanaan harga berpengaruh positif signifikan terhadap kinerja usaha dengan besaran pengaruh sebesar $\beta_{1}=0,352440$ dan $t_{\text {-statistic }}(=1,952253)>t_{a, n-k-1}\left(t_{\text {tabel }}=1,753\right)$. 
Penerapan kebijaksanaan/strategi harga oleh para pelaku usaha pada industri fotografi, yaitu dengan cara memperhatikan indikator tersebut di atas diharapkan akan meningkatkan kinerja usaha perusahaan-perusahaan pada industri jasa fotografi di Bandar Lampung.

\section{Kebijaksanaan/Strategi Promosi}

Berdasarkan hasil analisis deskriptif ,capaian target penerapan strategi promosi sebesar 73 persen. Adapun bentuk promosi yang dilakukan perusahaan pada industri jasa fotografi di Kota Bandar Lampung : (1).dilakukan secara langsung/lisan pada saat konsumen akan menyewa kamera (sebagai alternatif jasafoto grafi) dengan cara memberi informasi promosi agar konsumen lebih memilih jasa fotografi daripada menyewa kamera, (2).menyebarkan pamflet, dan (3).industri jasa fotografi juga memanfaatkan media sosial dalam kegitan promosinya, yaitu dengan membuat akun resmi industri fotografi pada aplikasi facebook, dan instagram.

Tingkat intensitas pelaksanaan promosi, berpengaruh negatif kecil dan signifikan terhadap kinerja usaha yaitu sebesar $\beta_{3}=-0,322344$ dan $t_{\text {-statistic }}=-2.629373>t_{\alpha, n-k-1}\left(t_{\text {-tabel }}=-\right.$ 1,753). Hasil ini menunjukkan bahwa Intensitas penerapan strategi promosi yang dilakukan perusahaan dalam industri fotografi tidak berdampak langsung terhadap upaya peningkatan nilai penjualan perusahaan, hal ini berarti penerapan kebijaksanaan/strategi promosi lebih cenderung berfungsi sebagai pemberian informasi bagi calon konsumen daripada berfungsi sebagai upaya untuk meningkatkan nilai penjualan perusahaan.

\section{Kebijaksanaan/Strategi Peningkatan Kualitas Pelayanan}

Hasil analisis deskriptif menunjukkan bahwa skor total ideal yang harus dicapai atas penerapan strategi peningkatan kualitas layanan adalah sebesar 400 dan skor total riil sebesar 258 dengan tingkat capaian skor ideal sebesar 64 persen. Hal ini menunjukkan bahwa perusahaan-perusahaan pada industri fotografi di Kota Bandar Lampung telah memberikan fasilitas layanan yang baik antara lain : (a).ketersediaan ruang tunggu yang nyaman yang didukung dekorasi yang baik, (b).tersedianya penyejuk ruangan, (c).tersedianya wifi dan air mineral di setiap ruangan. Pada aspek perhatian terhadap konsumen menunjukan bahwa responden cukup memperhatikan keluhan konsumen. Kemudian pada aspek intensitas penanganan keluhan konsumen mencapai pencapaian tertinggi yaitu sebesar 77 persen. Intensitas keluhan konsumen ini meliputi seberapa sering terjadinya keluhan yang disampaikan konsumen kepada perusahaan.Adapun bentuk keluhan yang disampaikan adalah berupa ketidak sesuaian keinginan/selera konsumen terhadap hasil fotografi.

Kualitas penerapan kebijaksanaan/strategi kualitas layanan yang di indikasikan : (1).aspek ketersediaan fasilitas yang diberikan kepada konsumen, (2).perhatian terhadap keluhan konsumen, intensitas penaganan keluhan konsumen, dan cara khusus dalam menerima keluhan, berpengaruh positif signifikan terhadap kinerja usaha dengan besaran pengaruh sebesar $\beta_{2}=0,399136$ dan $t_{\text {-statistic }}=1,951153>t_{a, n-k-1}\left(t_{\text {tabel }}=1,753\right)$.

Selanjutnya secara menyeluruh/ bersama-sama variabel kebijak-sanaan/ strategi penerapan harga, kebijaksanaan/ strategi Peningkatan kualitas layanan, kebijaksanaan/ strategi penerapan promosi, dan kebijaksanaan/strategi pengem-bangan produk berpengaruh signifikan sebesar 76,80\% terhadap kinierja usaha perusahaan-perusahaan pada industri jasa fotografi di Bandar Lampung dan sisanya sebesar $23,20 \%$ dipengaruhi variabel lain di luar model. Hal ini di tunjukkan oleh koefisien determinasi $R_{\text {-squared }}=0,767970$ dengan $F_{\text {-statistic }}\left(F_{h}=12.41172\right)>F_{a, n-k-1}$ $\left(F_{t}=4,56\right)$

\section{KESIMPULAN DAN SARAN}

\section{Kesimpulan}

1. Struktur pasar industri jasa fotografi di Kota Bandar Lampung yang di ukur menggunakan market share dan indeks herfindal adalah tergolong kedalam pasar persaingan monopolistik atau termasuk kedalam industri yang tidak terkonsentrasi.

2. Perilaku usaha yang di ukur berdasarkan aspek kebijak-sanaan/ strategi produk, strategi harga, strategi harga pesaing, dan strategi peningkatan kualitas pelayanan telah berjalan 
efektif. Hal ini ditunjukkan dengan kondisi pencapaian efektivitas strategi produk sebesar 67,6 persen, strategi harga sebesar 66 persen, strategi pemasaran dan promosi sebesar 73 persen, dan strategi kualitas pelayanan sebesar 64 persen.

3. Persentase capaian kondisi ideal kinerja usaha industri fotografi di Kota Bandar Lampung yang dinilai berdasarkan jumlah paket yang terjual, nilai penjualan, persentase pertumbuhan nilai penjualan, persentase capaian target nilai penjualan yaitu sebesar 67,25 persen.

4. Hasil analisis asosiatif menunjukkan:

a. Kualitas implementasi kebijaksanaan produk berpengaruh positif signifikan terhadap kinerja usaha,

b. Kualitas implementasi kebijaksanaan harga berpengaruh positif signifikan terhadap kinerja usaha,

c. Tingkat intensitas pelaksanaan promosi, berpengaruh negatif kecil signifikan terhadap kinerja usaha, yang berarti penerapan strategi promosi yang dilakukan perusahaan tidak berpengaruh terhadap peningkatan nilai penjualan perusahaan, melainkanhanya berfungsi sebagai pemberian informasi bagi calon konsumen., dan

d. Kualitas penerapan kebijaksanaan/strategi kualitas layanan berpengaruh positif signifikan terhadap kinerja usaha.

5. Secara menyeluruh/bersama-sama variabel kebijaksa-naan/strategi penerapan harga, kebijaksanaan/ strategi pening-katan kualitas layanan, kebijaksanaan/strategi pene-rapan promosi, dan kebijak-sanaan/strategi pengembangan produk berpengaruh signifikan sebesar 76,80 \% terhadap kinierja usaha perusahaan-perusahaan pada industri jasa fotografi di Bandar Lampung dan sisanya sebesar 23,20 \% dipengaruhi variabel lain di luar model.

\section{Saran}

1. Pelaku usaha industri fotografi di Kota Bandar Lampung berada pada pasar persaingan monopolistik, oleh karena itu perusahaan tidak dianjurkan untuk sering menerapkan kebijaksanaan/strategi harga (menaikkan harga), karena naiknya harga sensitif terhadap penurunan jumlah barang yang diminta yang pada akhirnya akan menurunkan penerimaan perusahaan.

2. Pelaku usaha industri fotografi di Kota Bandar lampung perlu untuk menambah tim kreatif guna dapat memberikan kontribusi dalam perusahaan untuk mengemas produk dengan lebih menarik. Perusahaan Industri jasa fotografi di Kota Bandar Lampung juga perlu memperhatikan keluhan dan saran dari konsumen dalam menentukan konsep studio untuk menyesuaikan minat dan kebutuhan konsumen.

3. Pelaku usaha pada industri jasa fotografi di Kota Bandar Lampung harus lebih memperhatikan banyak hal, seperti:

a. Ongkos produksi,

b. Kondisi permintaan konsumen,

c. Harga pesaing dan faktor lainnya dalam penetapan harga produk dan penerapan strategi harga, karena perusahaan-perusahaan dalam industri ini berada dalam struktur pasar persaingan monopolistik.

4. Pelaku usaha industri jasa fotografi di Kota Bandar Lampungperlu lebih memperhatikan harga/sewa kamera yang di tetapkan oleh penyedia jasa sewa kamera,karena jasa sewa kamera merupakan barang subtitusi dari paket fotografi.

5. Pelaku usaha industri jasa fotografi di Kota Bandar Lampung perlu memiliki cara dan kontak khusus dalam menerima keluhan konsumen. Oleh sebab itu pelaku usaha fotografi perlu menyediakan layanan khusus dalam menerima keluhan dan saran dari konsumen seperti penyediaan layanan feedback via web untuk menerima masukan dan keluhan dari konsumen. 


\section{DAFTAR PUSTAKA}

Arsyad, Lincolin dan Eri Kusuma, Stephanus. (2014). Ekonomika Industri (Pendekatan Struktur, Perilaku, dan Kinerja). Penerbit UPP STIM YKPN. Cetakan Pertama Tahun. Yogyakarta.

Badan Pusat Statistik. (2017). Tentang : “Jasa”. Jakarta. Indonesia.

Badan Pusat Statistik. (2017). Kota Bandar Lampung Dalam Angka. Bandar Lampung. Lampung.

Hasibuan, Nurimansjah. (1994). "Ekonomi Industri”. LP3ES. Jakarta.

Kirana Jaya, Wihana. (2001). "Pengantar Ekonomi Industri : Pendekatan Struktur Prilaku dan Kinerja". BPFE. Yogyakarta

Kuncoro, Mudrajad. (2007). "Ekonomika Industri Indonesia”. ANDI. Yogyakarta.

Triadi, Darwis. (2008). "Mata Hati Hidup, Anugrah dan Fotografi”. GM. Jakarta.

Teguh. Muhammad. (2013). "Ekonomi Industri”. Raja Grafindo Persada. Jakarta. 